\title{
Analisis Kemampuan Berpikir Reflektif Dalam Menyelesaikan Soal Cerita Materi Persegi Bagi SiswaKelas VIII SMP Kristen 02 Salatiga Tahun Ajaran 2017/2018
}

\author{
Christiana Kartika Dian', Kriswandani², Novisita Ratu ${ }^{3}$ \\ ${ }^{1}$ Pendidikan Matematika, Universitas Kristen Satya Wacana, 202014006@student.uksw.edu \\ ${ }^{2}$ Pendidikan Matematika, Universitas Kristen Satya Wacana, kriswandani@staff.uksw.edu \\ ${ }^{3}$ Pendidikan Matematika, Universitas Kristen Satya Wacana, novisita.ratu@staff.uksw.edu
}

\begin{abstract}
INFO ARTIKEL
RiwayatArtikel:

Diterima: 10-02-2018

Disetujui: 06-03-2018
\end{abstract}

\section{Kata Kunci:}

Reflektif

Soal cerita

Segi empat

\begin{abstract}
ABSTRAK
Abstrak: Berpikir reflektif merupakan kegiatan yang membuat siswa berusaha menghubungkan pengetahuan yang diperolehnya untuk menyelesaikan permasalahan baru yang berkaitan dengan pengetahuan lamanya. Berpikir reflektif meliputi tiga fase/ tingkat yaitu reacting (berpikir reflektif untuk aksi), comparing (berpikir reflektif untuk evaluasi) dan contemplating (berpikir reflektif untuk inkuiri kritis). Untuk mengetahui tingkat kemampuan berpikir reflektif siswa, maka dilakukan penelitian dengan jenis deskriptif kualitatif. Subjek penelitian ini adalah 3 siswi kelas VIII SMP Kristen 02 Salatiga yang dipilih secara purposive sampling pada materi bangun datar segi empat dengan kemampuan awal yang berbeda. Dari hasil analisis, siswa berkemampuan awal tinggi dapat dikatakan reflektif, kemampuan awal sedang dikatakan cukup reflektif, dan kemampuan awal rendah dikatakan kurang reflektif.

Abstract: Reflective thinking is an activity that keeps students trying to connect their acquired knowledge to solve new problems related to their old knowledge. Reflective thinking involves three phases / levels of reacting (thinking reflectively for action), comparing (reflective thinking for evaluation) and contemplating (reflective thinking for critical inquiry). To know the level of reflective thinking ability of students, then conducted research with descriptive qualitative type. The subjects of this study were 3 VIII grade students of SMP Kristen 02 Salatiga who were chosen by purposive sampling on the rectangular building material with different initial capability. From the results of the analysis, high initial students can be said to be reflective, the initial ability is said to be quite reflective, and low initial ability is said to be less reflective.
\end{abstract}

\section{A. LATAR BELAKANG}

Kusumaningrum (2012: 573) mengungkapkan bahwa matematika melatih cara berpikir dan bernalar dalam menarik kesimpulan, misalnya melalui kegiatan penyelidikan, eksplorasi, eksperimen, menunjukkan kesamaan, perbedaan, konsisten dan inkonsistensi. Kemampuan berpikir matematika menjadi salah satu tolak ukur tercapainya tujuan pembelajaran matematika, terutama kemampuan berpikir tingkat tinggi (high order thinking skill), seperti kemampuan berpikir kritis, kreatif, logis, analitis, dan reflektif.

Salah satu kemampuan berpikir tingkat tinggi adalah berpikir reflektif. Menurut Rahmy (2012: 33), berpikir reflektif merupakan suatu kegiatan berpikir yang dapat membuat siswa berusaha menghubungkan pengetahuan yang diperolehnya untuk menyelesaikan permasalahan baru yang berkaitan dengan pengetahuan lamanya.

Nindiasari (2013) mengatakan bahwa kemampuan berpikir reflektif merupakan salah satu kemampuan yang diperlukan dalam pembelajaran matematika. Hal tersebut dikarenakan target-target pembelajaran matematika seperti pemahaman, pemecahan masalah, koneksi, dan komunikasi matematika, serta kemampuan lainnya akan dimiliki oleh siswa dengan baik apabila siswa mampu menyadari apa yang dilakukan sudah tepat, dan dapat menyimpulkan apa yang seharusnya dilakukan bila mengalami kegagalan, serta dapat mengevaluasi apa yang telah dilakukan.

Seberapa besar kemampuan berpikir reflektif siswa dapat diketahui oleh seorang pendidik dengan dilakukannya serangkaian aktivitas yang bisa membuat siswa menunjukkan kemampuan berpikir reflektifnya. Salah satu aktivitas tersebut adalah dengan memecahkan masalah matematika.

Memecahkan masalah dalam matematika sangat memerlukan pemahaman konsep, karena konsep dalam matematika sering kali saling berkaitan. Apabila mereka kurang menguasai sebuah konsep, maka mereka akan mengalami kesulitan saat menghubungkan konsep matematika yang pernah mereka dapatkan sebelumnya dengan materi baru yang mereka dapatkan. Fitriana (2013) mengatakan bahwa jika keadaan tersebut terus berlanjut, tentu akan mengakibatkan dangkalnya pengetahuan siswa karena kurangnya pemahaman sebuah konsep. Misalkan siswa kurang memahami konsep dari geometri bangun 
datar, maka siswa tersebut akan kesulitan dalam penguasaan materi serta kegiatan yang berhubungan dengan materi tersebut salah satunya adalah memecahkan masalah geometri bangun datar.

Suharna (2013) berpendapat bahwa dalam pembelajaran matematika, siswa dilatih untuk berpikir dan memecahkan masalah dengan baik, untuk itu peserta didik dilatih untuk memecahkan masalah dengan kemampuan berpikir tingkat tinggi. Selama ini kecenderungan siswa dalam mempelajari matematika fokus pada masalah hafalan rumus dalam menyelesaikan masalah. Mereka berpikir hanya dengan menghafalkan rumus bisa menemukan solusi dari permasalahan.

Suherman (2002) mengatakan bahwa pemecahan masalah merupakan bagian terpenting dalam matematika, bahkan masuk dalam bagian kurikulum matematika. Hal ini dikarenakan dalam proses pembelajaran diperlukan pemecahan dalam setiap masalah yang ada. Memecahkan masalah matematika dapat memacu fungsi otak untuk mengembangkan daya pikir siswa secara kreatif dalam mengenali permasalahan dan mencari alternatif dalam pemecahannya. Syah (2004) menyatakan bahwa tujuan dari belajar memecahkan masalah adalah untuk memperoleh kemampuan dan kecakapan kognitif secara rasional, lugas, dan tuntas.

Pembelajaran matematika yang dilaksanakan di kelas VIII SMP Kristen 02 Salatiga tidak hanya dilaksanakan dengan metode ceramah, tetapi juga telah dilaksanakan dengan menggunakan model pembelajaran kooperatif dengan tahapan diskusi siswa yang dibimbing oleh guru. Walaupun demikian, guru masih banyak berperan aktif dalam menemukan konsep dalam menyelesaikan permasalahan, siswa masih cenderung hafalan dan kecepatan berhitung saja, sehingga siswa kurang membuka wawasan pengetahuan. Hal tersebut dapat menyebabkan siswa kurang aktif baik dalam berpikir maupun bertindak karena pembelajaran masih didominasi oleh guru. Keadaan yang demikian menyebabkan siswa kurang dalam kemampuan menyelesaikan masalah matematika terutama pada soal cerita serta ketertarikan siswa dalam menyelesaikan pemecahan masalah matematika masih kurang.

Teori Surbeck, Han dan Moyer dalam Noer (2010) mengutarakan bahwa kemampuan berpikir reflektif adalah kemampuan mengidentifikasi apa yang sudah diketahui, menerapkan pengetahuan yang dimiliki dalam situasi yang lain, memodifikasi pemahaman berdasarkan informasi dan pengalaman-pengalaman baru yang meliputi tiga fase/ tingkat yaitu reacting (berpikir reflektif untuk aksi), comparing (berpikir reflektif untuk evaluasi) dan contemplating (berpikir reflektif untuk inkuiri kritis), sehingga siswa dengan kemampuan berpikir reflektif yang baik akan memiliki pemahaman masalah yang baik pula, memiliki kemampuan menyusun dan menerapkan strategi penyelesaian dan mampu membuat kesimpulan dengan benar.

Pentingnya kemampuan berpikir reflektif telah terbukti dari penelitian yang telah dilakukan oleh Nindiasari (2014: 82) yang dilakukan di salah satu SMA di Kabupaten Tangerang Propinsi Banten, yang menyebutkan bahwa kemampuan berpikir reflektif siswa belum menunjukkan hasil yang memuaskan. Penelitian yang juga dilakukan oleh Noer (2008) dan Suharna (2013) telah menunjukkan bahwa siswa yang menggunakan proses berpikir reflektif memberikan hasil yang lebih baik jika dibandingkan dengan pembelajaran biasa.

Berdasarkan uraian permasalahan di atas, penulis tertarik untuk melakukan penelitian dengan topik "Analisis Kemampuan Berpikir Reflektif Dalam Menyelesaikan Soal Cerita Matematika Subpokok Bahasan Geometri Bangun Datar Bagi Siswa Kelas VIII SMP Kristen 02 Salatiga Tahun Ajaran 2017/2018".

Mengacu pada latar belakang masalah yang diuraikan pada bagian pendahuluan di atas, maka dapat dirumuskan permasalahannya adalah bagaimanakah kemampuan berpikir reflektif siswa kelas VIII SMP Kristen 02 Salatiga dalam menyelesaikan soal cerita pada materi geometri bangun datar?.

Pada dasarnya tujuan penelitian ini adalah mencari jawaban atas masalah penelitian yang telah dirumuskan. Adapun tujuan penelitian ini adalah mendeskripsikan kemampuan berpikir reflektif siswa kelas VIII SMP Kristen 02 dalam menyelesaikan soal cerita pada materi geometri bangun datar.

\section{B. METODE PENELITIAN}

Jenis penelitian yang digunakan dalam penelitian ini adalah penelitian kualitatif. Subjek penelitian ini adalah 3 siswa kelas VIII SMP Kristen 02 Salatiga pada semester genap tahun ajaran 2017/2018. Pengambilan sampel dengan menggunakan purposive sampling, yaitu siswa langsung ditunjuk untuk dijadikan subyek penelitian. Pengambilan sampel berdasarkan pertimbangan antara peneliti dan guru matematika, serta mampu mengungkapkan pendapat serta cara berpikirnya baik secara lisan maupun tulisan.

Pada penelitian ini peneliti menggunakan teknik pengumpulan data dengan cara dokumentasi, tes dan wawancara. Hasil tes atau data dalam penelitian ini akan menjadi bahan yang akan dianalisis mengenai kemampuan berpikir reflektif dalam menyeleaikan soal cerita. Wawancara dilakukan secara mendalam (in depth interview) dan bersifat semi terstruktur. Instrumen bantu yang digunakan dalam penelitian ini berupa soal cerita yang memenuhi indikator berpikir reflektif.

Data yang diperoleh dianalisis dengan menggunakan pedoman indikator yang telah dibuat untuk memperoleh data siswa yang dapat dijadikan subjek wawancara. Indikator berpikir reflektif dalam penelitian ini diadaptasi dari Surbeck, Han Moyer dalam Noer yang meliputi tiga tingkatan/ fase yaitu Reacting, Comparing dan Contemplating,yaitu :

TABEL 1

INDIKATOR KEMAMPUAN BERPIKIR REFLEKTIF

Fase/ Tingkatan Sumber asli

1. Reacting (berpikir reflektif Pada tingkat ini siswa untuk aksi), dalam fase ini cenderung

hal-hal yang dilakukan siswa menggunakan sumber adalah :

a. Menyebutkan apa yang Curiosity(keingintahuan ditanyakan. dalam pemahaman

b. Menyebutkan apa yang masalah) diketahui.

c. Mampu menjelaskan apa yang diketahui sudah cukup untuk menjawab yang ditanyakan 
2. Comparing (berpikir reflektif untuk evaluasi), pada fase ini siswa melakukan beberapa hal berikut :

a. Mengaitkan masalah yang ditanyakan dengan masalah yang pernah dihadapi.

\begin{tabular}{|c|c|c|}
\hline 3 & $\begin{array}{l}\text { Contemplating (berpikir } \\
\text { reflektif untuk inkuiri kritis), } \\
\text { pada fase ini siswa } \\
\text { melakukan beberapa hal } \\
\text { berikut: }\end{array}$ & $\begin{array}{l}\text { Pada tingkat ini siswa } \\
\text { cenderung } \\
\text { menggunakan sumber } \\
\text { asli berupa Orderlinnes } \\
\text { (Keteraturan) }\end{array}$ \\
\hline a. & $\begin{array}{l}\text { Menjelaskan apa } \\
\text { dikerjakan }\end{array}$ & $\begin{array}{l}\text { berdasarkan Curiosity } \\
\text { (keingintahuan) dan }\end{array}$ \\
\hline b. & Mendeteksi kesalahan & Suggestion (saran). \\
\hline c. & $\begin{array}{l}\text { Memperbaiki } \\
\text { menjelaskan } \\
\text { kesalahan }\end{array}$ & \\
\hline
\end{tabular}

Teknik analisis data dilaksanakan dengan cara: (1) pengumpulan data, (2) reduksi data, pengurangan informasi yang tidak perlu, pengorganisasian data, dan verifikasi jawaban siswa, (3) display data, data disajikan dalam bentuk teks yang bersifat naratif yang disusun dengan baik dan runtut agar mudah dilihat, dibaca, dan dipahami, dan (4) verifikasi dan penegasan kesimpulan.

\section{HASIL DAN PEMBAHASAN}

Hasil wawancara yang telah dianalisis kemudian dibandingkan untuk memperoleh data yang valid. Selanjutnya dapat diketahui proses berpikir reflektif siswa dalam menyelesaikan soal cerita matematika. Proses berpikir reflektif siswa dalam menyelesaikan soal cerita matematika dapat dilihat pada Tabel 2.

\section{TABEL 2}

TINGKAT KEMAMPUAN BERPIKIR REFLEKTIF SISWA DALAM MENYELESAIKAN SOAL CERITA MATEMATIKA

\begin{tabular}{cccc}
\hline Inisial & Kategori Secara & \multicolumn{2}{c}{ Soal } \\
\cline { 3 - 4 } & Kognitif & $\mathbf{1}$ & $\mathbf{2}$ \\
\hline$S_{1}$ & Tinggi & Reflektif & Reflektif \\
\hline$S_{2}$ & Sedang & Cukup & Reflektif \\
\hline$S_{3}$ & Rendah & Kurang & Kurang \\
\hline
\end{tabular}

Berdasarkan analisis data yang telah dilakukan, diketahui jika subjek $\mathrm{S}_{1}$ dalam memenuhi fase Reacting pada soal nomor 1 mampu mengungkapkan apa yang diketahui dan apa yang ditanyakan dengan sangat jelas dan rinci. Subjek $S_{1}$ juga dapat menyebutkan hubungan antara yang ditanya dengan yang diketahui, mampu menjelaskan apa yang diketahui sudah cukup untuk menjawab yang ditanyakan. Dalam memenuhi fase Comparing, subjek $\mathrm{S}_{1}$ dapat menjelaskan hubungan atau kaitan antara permasalahan yang pernah dihadapi sebelumnya dengan permasalahan yang sedang dihadapi. Kemudian dalam memenuhi fase Contemplating, subjek $\mathrm{S}_{1}$ dapat menjelaskan bagaimana cara pengerjaannya dengan jelas dan benar, subjek $S_{1}$ juga dapat mendeteksi kesalahan terhadap jawaban yang diutarakan. Dari permasalahan soal nomor 1dapat disimpulkan bahwa untuk proses berpikir dalam menyelesaikan soal matematika subjek $S_{1}$ yaitu reflektif.
Subjek $\mathrm{S}_{1}$ dalam memenuhi fase Reacting pada soal nomor 2 dapat menyebutkan apa yang diketahui dalam soal dengan sangat baik. Subjek juga dapat meyebutkan apa yang ditanyakan dan dapat menyebutkan hubungannya. Dalam memenuhi fase Comparing, subjek $\mathrm{S}_{1}$ dapat mengingat kembali masalah yang hampir sama dengan yang sedang dihadapi sekarang dan dapat juga menjelaskan hubungannya. Kemudian dalam fase Contemplanting, subjek $\mathrm{S}_{1}$ dapat menjelaskan bagaimana cara pengerjaannya dengan benar. Subjek tersebut juga dapat mendeteksi kesalahan terhadap jawabannya. Sehingga dapat disimpulkan bahwa subjek $\mathrm{S}_{1}$ dalam menyelesaikan soal nomor 2 adalah reflektif.

Analisis yang telah dilakukan kepada subjek $S_{2}$ dalam fase Reacting pada soal nomor 1 adalah subjek dapat menyebutkan apa yang diketahui dalam soal, dapat menyebutkan apa yang ditanyakan, serta dapat juga menjelaskan hubungan antara apa yang diketahui dan apa yang ditanyakan. Pada fase Comparing, subjek tidak dapat mengingat permasalahan yang dahulu pernah didapat. Subjek $S_{2}$ juga tidak dapat menjelaskan hubungannya, sehingga pada tahap ini tidak terpenuhi. Kemudian pada fase Contemplanting, subjek $\mathrm{S}_{2}$ dapat menjelaskan bagaimana cara menyelesaikan permasalahan tersebut. Subjek $S_{2}$ juga dapat mendeteksi kesalahan terhadap jawabannya. Dari permasalahan soal nomor 1 , subjek $S_{2}$ dapat dikatakan cukup reflektif.

Subjek $\mathrm{S}_{2}$ pada soal nomor 2 dapat memenuhi fase Reacting karena subjek dapat menyebutkan apa yang diketahui dalam soal dengan benar. Subjek $S_{2 j u g a}$ dapat menyebutkan yang ditanyakan oleh soal pada nomor 2 , dan dapat menjelaskan kaitannya. Pada fase Comparing, subjek dapat mengingat permasalahan yang pernah dihadapinya, dan memiliki kesamaan dengan permasalahan yang sekarang sedang dihadapinya. Subjek $\mathrm{S}_{2}$ juga dapat menjelskan hubungan atau kaitan antara permasalahan yang pernah dihadapi sebelumnya dengan permasalahan yang sekarang. Sedangkan pada fase Contemplating, subjek dapat menjelaskan cara pengerjaannya dengan benar. Serta dapat mendeteksi kesalahan pada pekerjaannya. Sehingga, pada permasalahan soal nomor 2 , subjek $S_{2}$ dapat dikatakan reflektif.

Berdasarkan analisa yang dilakukan, diketahui bahwa subjek $\mathrm{S}_{3}$ dalam memenuhi fase Reacting pada soal nomor 1 mampu menyebutkan apa yang diketahui dalam soal dengan baik, sunjek juga dapat menyebutkan apa yang ditanyakan dari permasalahan tersebut dan dapat menjelaskannya. Pada fase Comparing tidak dapat terpenuhi karena subjek $\mathrm{S}_{3}$ tidak dapat mengingat permasalahan yang hampir sama dan yang pernah dihadapi. Subjek juga tidak dapat menjelaskan permasalahan yang pernah dihadapi sebeumnya, dan tidak dapat menjelaskan keterkaitannya. Kemudian pada fase Contemplanting tidak dapat terpenuhi karena sunjek $\mathrm{S}_{3}$ hanya dapat menjelaskan bagaimana cara mengerjakannya, walaupun dengan jawaban yang salah. Maka pada permasalahan soal nomor 1 , subjek $S_{3}$ dapat dikatakan kurang reflektif.

Subjek $\mathrm{S}_{3}$ dalam memenuhi fase Reacting pada soal nomor 2 mampu menyebutkan apa yang diketahui dalam soal. Subjek juga dapat menyebutkan apa yang diketahui, serta dapat menjelaskan hubungan dari apa yang diketahui dan apa yang ditanyakan. Pada fase Comparing tidak dapat 
terpenuhi karena subjek hanya dapat menyebutkan bahwa subjek tersebut sudah pernah mendapatkan soal yang hampir sama dengan permasalahan yang sekarang, namun subjek $\mathrm{S}_{3}$ tersebut tidak dapat menjelaskan permasalahan yang pernah dihadapi, dan tidak dapat menjelaskan hubungan dari permasalahan tersebut. Kemudian subjek $S_{3}$ dikatakan tidak memenuhi fase Contemplanting karena subjek hanya dapat menjelaskan apa yang sudah dikerjakan. Subjek $\mathrm{S}_{3}$ tersebut tidak dapat mendeteksi kesalahan terhadap apa yang sudah dikerjakan. Serta tidak dapat mendeteksi kesalahannya. Maka, pada permasalahan soal nomor 2 , subjek $S_{3}$ dapat dikatakan kurang reflektif.

\section{SIMPULAN DAN SARAN}

Berdasarkan hasil penelitian dan pembahasan, tentang proses berpikir reflektif, diperoleh kesimpulan berikut. Subjek $S_{1}$ dengan kemampuan awal matematika tinggi menunjukkan proses berpikir reflektif dalam menyelesaikan soal cerita matematika, subjek $\mathrm{S}_{1}$ melalui ketiga fase dalam kedua soal yang diberikan dan mememenuhi semua indikator berpikir reflektif, sehingga dapat dikatakan bahwa subjek $\mathrm{S}_{1}$ reflektif.

Subjek $\mathrm{S}_{2}$ dengan kemampuan awal matematika sedang menunjukkan proses berpikir cukup reflektif dalam menyelesaikan soal cerita matematika, subjek $\mathrm{S}_{2}$ melalui 2 fase pada soal nomor 1 yaitu fase Reacting dan fase Contemplating. Seangkan pada soal nomor 2 , subjek $\mathrm{S}_{2}$ dapat melewati ketiga fase dan memenuhi semua indikator berpikir reflektif. Dengan demikian subjek $S_{2}$ dengan kemampuan awal matematika sedang dapat dikatakan cukup reflektif.

Subjek $\mathrm{S}_{3}$ dengan kemampuan awal matematika rendah menunjukkan proses berpikir kurang reflektif dalam menyelesaikan soal cerita matematika. Subjek $\mathrm{S}_{3}$ hanya melalui 1 fase pada kedua soal yangdiberikan, yaitu fase Reacting. Sehingga subjek $\mathrm{S}_{3}$ dapat dikatakan kurang reflektif.

Berdasarkan hasil penelitian, pembahasan dan simpulan dari penelitian ini, dapat diajukan saran-saran sebagai berikut :

a) Bagi guru, hendaknya memberikan pengajaran yang dapat mendorong siswa untuk berperan aktif, baik yang berkemampuan matematika tinggi, sedang, ataupun rendah. Agar semua siswa dapat meningkatkan kemampuan berpikirnya.

Bagi peneliti lain, diharapkan dapat mengembangkan secara luas dan mendalam mengenai kemampuan berpikir reflektif siswa.

\section{UCAPAN TERIMA KASIH}

Penulis mengucapkan banyak terimakasih kepada dosen pembimbing yang telah dengan sabar membimbing dalam penulisan jurnal ini dari awal hingga akhir. Terimakasih pula untuk guru matematika di SMP Kristen 02 salatiga yang telah memberikan ijin untuk melakukan penelitian, dan tak lupa terimakasih juga penulis ucapkan untuk ketiga subjek penelitian yang mau memberi waktunya untuk membantu berjalannya penelitian yang penulis lakukan.

\section{DAFTAR RUJUKAN}

[1] Fitriana, L. Analisis Pemahaman Siswa Mengenai Konsep Limit Fungsi Berdasarkan Teori APOS Ditinjau dari Gaya Kognitif (Field Dependent dan Field Dependent) di Kelas XI IPA 2 MAN Rejotangan Tahun 2012/2013, (Tulungagung :Skripsi Tidak Diterbitkan, 2013), hal. 4

[2] Kusumaningrum, M. Dan Saefudin, A. "Mengoptimalkan Kemampuan Berpikir Matematika Melalui Pemecahan Masalah Matematika", Makalah ini disampaikan dalam Seminar Nasional Matematika dan Pendidikan Matematika, Yogyakarta, 10 November 2012, hlm. 571-572

[3] Nindiasari, H. Pendekatan Metakognitif Untuk Meningkatkan Kemampuan Berpikir Reflektif Matematis Siswa SMA, Jurnal Ilmu Pendidikan dan Pengajaran, Vol. 1 No. 1, Maret 2014

[4] Noer, S. H. (2010). Peningkatan Kemampuan Berpikir Kritis, Kreatif, Dan Reflektif (K2R) Matematis Siswa SMP Melalui Pembelajaran Berbasis Masalah. Disertai UPI: Tidak diterbitkan

[5] Rahmy, Z. "Pengaruh Pembelajaran dengan Pendekatan Proses Berpikir Reflektif terhadap Peningkatan Kemampuan Konesi dan Berpikir Kritis Matematis Siswa", Tesis, Jurusan Pendidikan Matematika Universitas Pendidikan Indonesia Bandung, 2012, hlm. 33

[6] Suherman, dkk., Strategi Pembelajaran Matematika Kontemporer edisi revisi (JICA), (Jakarta: Universitas Pendidikan Indonesia, 2002), hal: 89

[7] Suharna, H. dkk.,Berpikir Reflektif Mahasiswa dalam Menyelesaikan Masalah Matematika (Jurnal), KNPM V Himpunan Matematika Indonesia Juni 2013, hal: 281

[8] Syah, M. Psikologi Pendidikan dengan Pendekatan Baru, (Bandung: PT. Remaja Rosda Karya, 2004) hal:123 